\title{
PERAN BURSA KERJA KHUSUS (BKK) DALAM MENYALURKAN SISWA KOMPETENSI KEAHLIAN DESAIN PEMODELAN DAN INFORMASI BANGUNAN (DPIB) SMK N 2 KLATEN KE DUNIA INDUSTRI
}

\author{
Fany Dwi Sasongko ${ }^{1}$, Abdul Malik ${ }^{2}$, dan Sativa ${ }^{3}$ \\ ${ }^{123}$ Pendidikan Teknik Sipil dan Perencanaan, FT, UNY \\ Email: fany.dwi2016@student.uny.ac.id
}

\begin{abstract}
ABSTRAK
Penelitian ini bertujuan untuk mengkaji kinerja Bursa Kerja Khusus di SMKN 2 Klaten khususnya kompetensi keahlian Des ain Pemodelan dan Informasi Bangunan (DPIB). Pertama, bagaimana perannya dalam menyalurkan lulusan memasuki dunia indus tri. Kedua, untuk mengetahui kesiapan sis wa mendapatkanpekerjaan setelah mendapat bimbingan dari BKK. Ketiga, untuk menemukan hambatan yang dialami BKK serta upaya mengatasinya. Studi ini merupakan penelitian deskriptif kuantitatif. Subjek penelitian adalah 65 sis wa kelas XII kompetensi keahlian DPIB SMKN 2 Klaten tahun ajaran 2019/2020. Teknikpengumpulan data menggunakan kuesioner dengan skala Likert. Hasil kajian ini sebagai berikut: (1) Peran BKK SMKN 2 Klaten termas ukkategori tinggi dengan presentase $84 \%$. (2) Kesiapan siswa mendapatkan pekerjaan termasuk kategori cukup dengan presentase $77 \%$. (3) Hambatan y ang ada yaitu berkurangny a kerja s ama BKK dengan beberapaperusahaan. Upaya yang dilakukan untuk mengatasi hambatan ters ebut adalah BKK mencari dan melakukan pendekatan kepada perusahaan untuk menjalin kerja sama dalam hal penyaluran tenaga kerja.
\end{abstract}

Kata kunci: Bursa kerja khusus, Dunia industri

\begin{abstract}
This research aims to assess the performance of Bursa Kerja Khusus (Special Job Market) at SMKN2 Klaten, especially for the competency of Building Information and Modeling Design (DPIB). First, toexplorehow it plays a role in channeling graduates into the industrial world. Second, to determinethereadinessofstudentto get a job after receiving guidance from BKK. Third, to find obstacles experienced and to overcome them. This study is quantitative descriptive study. The subjects of this study were 65 students of classXIIofthe DPIBexpertise competency of SMKN 2 Klaten in the 2019/2020 school year. The data collection techniqueusedaquestionnaire with a Likert scale.The results of this study are as follows: (1) the role of $\mathrm{BKK}$ at $\mathrm{SMKN} 2 \mathrm{Klaten}$ is in the high category with a percentage of $84 \%$. (2) The readiness of students to get a job was categorizeda ssufficientwitha percentage of $77 \%$. (3) The existing obstacles is the reduce cooperation between BKK and severalcompanies. The effort to overcome the se obstacles are BKK seeking and approaching companies toestablishcooperationin terms of labor distribution.
\end{abstract}

Keywords: Special job market, Industrial world

\section{PENDAHULUAN}

Indonesia pada saat ini masih menjadi negara berkembang dalam perkembangan zaman. Jika dilihat dari sumber daya manusia yang ada, tingkat penganggurannya masih cukup tinggi. Jumlah penduduk yang terus bertambah mengakibatkan tingkat pengangguran semakin meningkat. Pengangguran yang semakin meningkat disebabkan ketatnya persaingan dalam dunia industri, kualitas sumber daya manusia, pertumbuhan penduduk, perkembangan dan perluasan ekonomi serta perkembangan teknologi yang pesat.

Perkembangan dan perluasan ekonomi di Indonesia membuat tenaga kerja yang dibutuhkan dalam dunia industri semakin banyak. Perkembangan teknologi yang semakin modern mengakibatkan meningkatnya syarat-syarat pengetahuan 
Peran Bursa Kerja Khusus ... (Fany/ hal. 175-189)

dan keterampilan kerja. Karena pada masa sekarang ini yang paling besar perannya adalah manusia berkualitas untuk menjalankan perkembangan zaman. Hal tersebut diharapkan dapat memacu dunia pendidikan untuk menghasilkan sumber daya manusia yang semakin berkualitas.

Pendidikan adalah pembelajaran, pengetahuan, keterampilan, dan kebiasaan sekelompok orang yang diturunkan dari satu generasi ke generasi berikutnya untuk menghasilkan individu yang lebih baik melalui pengajaran, pelatihan, atau penelitian. Pendidikan adalah proses yang berkelanjutan dan berlangsung seumur hidup dalam rangka mewujudkan manusia dewasa, mandiri dan bertanggungjawab. Hasil dari pendidikan sebagai wadah mengembangkan ilmu pengetahuan, kemampuan dan keterampilan individu, diharapkan mampu memberikan manfaat kepada lulusan sebagai bekal melanjutkan pendidikan yang lebih tinggi atau mampu memasuki dan bersaing di dunia industri. Salah satu cara untuk meningkatkan kualitas lulusan terutama dari segi keterampilan dapat dilakukan melalui pendidikan formal. Pendidikan formal tersebut bisa didapat melalui jalur pendidikan menengah kejuruan.

Sekolah Menengah Kejuruan (SMK) merupakan salah satu lembaga pendidikan formal yang dirancang untuk menghasilkan lulusan sebagai tenaga kerja yang mempunyai pengetahuan dan keterampilan yang siap kerja sesuai dengan bakat, minat dan kemampuannya. Hal tersebut diharapkan agar para lulusan nantinya dapat memasuki dunia kerja dan menjadi tenaga kerja yang kompeten di bidangnya seperti yang diungkapkan Munadi (Usman, 2012:7) "Pendidikan kejuruan merupakan salah satu jenis pendidikan yang menyiapkan peserta didik bekerja dalam bidang tertentu". Selanjutnya pengertian Sekolah Menengah Kejuruan menurut Peraturan Pemerintah Nomor 74 tahun 2008 tentang Guru pasal 1 ayat (21) yang berbunyi sebagai berikut: Sekolah Menengah Kejuruan yang selanjutnya disingkat SMK adalah salah satu bentuk satuan pendidikan formal yang menyelenggarakan pendidikan kejuruan pada jenjang Pendidikan Menengah sebagai lanjutan dari SMP, MTs, atau bentuk lain yang sederajat atau lanjutan dari hasil belajar yang diakui sama atau setara SMP atau MTs.

Sekolah Menengah Kejuruan (SMK) didukung dengan proses pembelajaran yang lebih banyak praktik menyerupai kondisi di dunia kerja sesuai bidangnya. Proses pembelajaran tersebut diciptakan guna mendukung kesiapan kerja siswa. SMK merupakan jembatan yang menghubungkan antara siswa dengan dunia kerja. Penilaian keberhasilan SMK dalam melaksanakan program pendidikan tidak hanya ditentukan oleh prestasi belajar yang tinggi dan banyaknya siswa yang lulus tetapi penilaian sesungguhnya dapat diukur dari keberhasilan lulusan di dunia kerja. Masalah terkait keberhasilan lulusan SMK dalam dunia kerja dapat diatasi melalui salah satu lembaga di sekolah yaitu Bursa Kerja Khusus (BKK).

Bursa Kerja Khusus (BKK) menurut Masdarini (2014:592) yaitu: Bursa Kerja Khusus merupakan unit kerja sekolah yang mempunyai potensi besar dalam menyalurkan para lulusan. BKK ditangani tim khusus untuk memberikan bimbingan karir sebelum lulusan dan pasca kelulusan. Bentuk bimbingan yang diberikan berupa penyuluhan strategi memasuki dunia kerja dan efektivitas melamar pekerjaan. Bursa Kerja Khusus (BKK) di sekolah merupakan unit kerja sekolah yang melaksanakan 
Peran Bursa Kerja Khusus ... (Fany/ hal. 175-189)

pelayanan dan sumber informasi tentang ketenagakerjaan. BKK bertujuan untuk membantu lulusan mencari dan mendapatkan pekerjaan yang sesuai bidangnya. Fungsi BKK memfasilitasi pencari kerja untuk mendapatkan pekerjaan atau sebagai mediator antara perusahaan dengan lulusan untuk mendapatkan pekerjaan. Keberadaan BKK di SMK sangat diperlukan bagi sekolah sebagai lembaga yang menyalurkan lulusan ke dunia kerja. Pengelolaan BKK secara optimal bisa menimbulkan dampak positif bagi sekolah dalam memenuhi permintaan tenaga kerja yang datang dari dunia usaha atau dunia industri (DU/DI) sesuai dengan persyaratan yang dibutuhkan.

Bursa Kerja Khusus diselenggarakan dengan tujuan untuk mendekatkan antara peluang kerja yang ada dengan SDM yang tersedia. Secara garis besar mekanisme kerja BKK yaitu menawarkan lulusan ke dunia kerja atau dunia industri, sedangkan dari pihak dunia usaha dan dunia industri menawarkan lowongan pekerjaan kepada BKK di sekolah. Kenyataannya saat ini bahwa sebagian lulusan masih mengalami kesulitan untuk mendapatkan pekerjaan.

Mekanisme kerja BKK secara garis besar menawarkan lulusan ke dunia indsutri sesuai dengan kompetensi keahlian masingmasing lulusan. Bursa kerja Khusus menurut Departemen Tenaga Kerja dan Transmigrasi RI, Dirjen Binapenta (2001: 3), memberikan rumusan bahwa: "BKK adalah suatu bursa kerja yang berada di satuan pendidikan menengah, pendidikan tinggi dan lembagalembaga pelatihan kerja lainnya yang mengadakan kegiatan pelayanan antar kerja bagi siswa lulusannya, memberikan informasi pasar kerja, pendaftaran pencari kerja, member penyuluhan dan bimbingan serta penyaluran dan penempatan tenaga kerja."

Kepengurusan BKK selama ini berjalan dengan baik dan lancar. Di bawah pimpinan Bapak Fajar. Pada saat ini kerjasama antara BKK dengan beberapa perusahaan masih terjaga. Diantaranya kerjasama dengan PT. Isuzu Astra Motor Indonesia, PT. Aisin, PT. Super Indo, PT. Hutama Karya yang beberapa perusahaan tersebut beroperasi di wilayah industri Jakarta dan Jawa barat. Salah satu bentuk kerjasama tersebut adalah rekrutmen dari perusahaan yang dilakukan melalui BKK SMKN 2 Klaten dan Tes rekrutmen yang juga di lakukan di SMK. Namun pada masa Revolusi Industri 4.0 sekarang ini, menurut Klaus (2017) "Revolusi Industri 4.0 telah mengubah hidup dan kerja manusia secara fundamental. Kemajuan teknologi baru yang mengintegrasikan dunia fisik, digital, dan biologis telah mempengaruhi semua disiplin ilmu, ekonomi, industri dan pemerintah.

Bidang-bidang yang mengalami terobosan berkat kemajuan teknologi baru diantaranya (1) robot kecerdasan buatan, (2) teknologi nano, (3) bioteknologi, teknologi computer kuantum, (5) blockhain, (6) teknologi berbasi internet, dan (7) printer 3D." Secara garis besar revolusi industri 4.0 adalah integrasi antara dunia internet dengan dunia usaha atau produksi di industri. Artinya semua proses produksi dijalankan dengan teknologi robot dan internet. Hal tersebut mengakibatkan kerja sama antara BKK dan perusahaan mulai berkurang, dan menyebabkan BKK kesulitan dalam memberikan informasi lowongan pekerjaan kepada lulusan. Kondisi tersebut menuntut BKK untuk mencari perusahaan-perusahaan baru guna memberi informasi kerja dan menyalurkan siswa/lulusan untuk bekerja di dunia industri. 
Peran Bursa Kerja Khusus ... (Fany/ hal. 175-189)

Konsep pekerjaan bagi masyarakat dapat dilihat dari berbagai sudut pandang, tetapi umumnya menyangkut pada dua hal, yaitu bekerja sebagai upaya pemenuhan kebutuhan jasmani: sandang, pangan, papan dsb. Serta kebutuhan rohani, pemenuhan kepuasan mental spiritual dan bernilai ibadah (Musnamar, 1992:120). Lebih lanjut Tohari mendeskripsikan faktor-faktor yang mempengaruhi keberhasilan kerja, yaitu keahlian, kemauan dan sikap positif, kesempatan dan peluang, imbalan yang layak, dan hubungan kerja yang manusiawi.

Kemitraan merupakan strategi yang dialukan oleh dua orang atau lebih untuk meraih suatu keuntungan bersama. Menurut Hafsah (2005:43) kemitraan adalah: suatu strategi bisnis yang dilakukan oleh dua pihak atau lebih dalam jangka waktu tertentu untuk meraih keuntungan bersama dengan prinsip saling membutuhkan dan saling membesarkan, karena merupakan strategi bisnis maka keberhasilan kemitraan sangat ditentukan oleh adanya kepatuhan diantara yang bermitra dalam menjalankan etika bisnis.

Menurut Mulyaningtyas dan Hidayanto (2006:126) mengatakan bahwa informasi dunia kerja "meliputi semua informasi mengenai peluang dan lowongan pekerjaan serta kiat dan cara untuk memasuki dunia kerja". Informasi dunia kerja berkaitan dengan peluang dan lowongan pekerjaan serta kiat dan cara memasuki dunia kerja. Sukardi dan Sumiati (2002:112) mengemukakan bahwa: "Pada dasarnya informasi pekerjaan atau karir terdiri dari fakta-fakta mengenai pekerjaan, jabatan atau karir dan bertujuan untuk membantu individu memperoleh pandangan, pengertian dan pemahaman tentang dunia kerja dan aspek-aspek dunia kerja".
Penarikan (rekrutmen) tenaga kerja merupakan tindak lanjut dari fungsi manajemen yang pertama yaitu pengadaan tenaga kerja. Pengadaan tenaga kerja meliputi proses mencari, menemukan, mengajak dan menetapkan sejumlah orang dari dalam maupun dari luar perusahaan sebagai calon tenaga kerja. Proses dimulai ketika para pelamar dicari dan berakhir bila lamaran mereka diserahkan ke perusahaan.

Menurut Mangkunegara (2009:33) mengatakan bahwa: "Penarikan adalah suatu proses atau tindakan yang dilakukan oleh perusahaan untuk mendapatkan tambahan pegawai yang melalui tahapan yang mencakup identifikasi dan evaluasi sumbersumber penarikan pegawai, menentukan kebutuhan pegawai yang diperlukan perusahaan, proses seleksi, dan orientasi pegawai".

Proses rekrutmen ini dilakukan apabila ada departemen yang memerlukan karyawan baru, bisa dikarenakan adanya karyawan yang berhenti atupun ada pekerjaan baru dan memerlukan penambahan karyawan. Rekrutmen karyawan untuk mengisi posisi yang masih kosong dapat dilakukan melalui berbagai sumber. Sumber rekrutmen dapat dilakukan diantaranya melalui sumber rekrutmen dari dalam (internal) perusahaan maupun dari luar (eksternal) perusahaan.

$$
\text { Menurut Hasibuan }
$$
mengatakan bahwa ada dua cara sumber penarikan atau rekrutmen tenaga kerja: 1) Sumber internal adalah karyawan yang akan mengisi lowongan yang lowong diambil dari dalam perusahaan tersebut, yakni dengan cara memutasikan atau memindahkan karyawan yang memenuhi spesifikasi pekerjaan jabatan itu. 2) Sumber eksternal adalah karyawan yang akan mengisi jabatan yang lowong dilakukan penarikan dari sumbersumber tenaga kerja dari luar 
perusahaan, antara lain berasal dari nepotisme pasar tenaga kerja dengan memasang iklan melalui media massa dan sumber-sumber lainnya.

Setelah tenaga kerja melalui proses rekrutmen maka proses selanjutnya yaitu proses seleksi. Proses seleksi dilakukan karena dalam proses rekrutmen belum menetapkan pegawai mana yang memenuhi syarat diterima atau ditolak pada suatu perusahaan atau instansi. Seleksi merupakan salah satu proses terpenting karena diterima atau tidaknya pelamar pekerjaan yang telah lulus dalam proses rekrutmen sangat ditentukan dalam proses seleksi. Menurut Sastrohadiwiryo (2005:149) seleksi tenaga kerja adalah "kegiatan untuk menentukan dan memilih tenaga kerja yang memenuhi kriteria yang telah ditetapkan perusahaan serta memprediksi kemungkinan keberhasilan/kegagalan individu dalam pekerjaan yang akan diberikan kepadanya". Seleksi tenaga kerja merupakan kegiatan dalam memilih calon tenaga kerja yang sesuai dengan kebutuhan pekerja pada perusahaan.

Penyaluran atau penempatan tenaga kerja merupakan kegiatan membantu pencari kerja supaya dapat memperoleh pekerjaan dan pemberi kerja terbantu dalam mengisi lowongan kerja sesuai dengan kriteria yang diinginkan pemberi kerja. Ardana, dkk (2012:82) menyatakan: Penempatan SDM adalah suatu proses pemberian tugas dan pekerjaan kepada karyawan yang lulus dalam seleksi untuk dilaksanakan secara continue dan wewenang serta tanggung jawab yang melekat sebesar porsi dan komposisi yang ditetapkan serta mampu mempertanggungjawabkan segala risiko yang mungkin terjadi atas tugas dan pekerjaan, wewenang dan tanggung jawab tersebut.
Berdasarkan dari uraian latar belakang di atas, maka peneliti tertarik untuk melakukan penelitian terkait "Peran Bursa Kerja Khusus (BKK) di SMKN 2 Klaten dalam menyalurkan siswa kompetensi keahlian Desain Pemodelan dan Informasi Bangunan (DPIB) ke dunia industri."

\section{METODE}

Penelitian tentang Peran BKK di SMKN 2 Klaten ini menggunakan metode penelitian deskriptif yaitu metode yang digunakan untuk mendapatkan data dari tempat tertentu yang alamiah (bukan buatan) tetapi penelitian melakukan perlakuan dalam pengumpulan data, misalnya dengan mengedarkan kuesioner, test, dan wawancara dalam pengumpulan data (Sugiyono, 2009).

Jenis penelitian ini adalah penelitian deskriptif kuantitatif. Penelitian ini memuat deskripsi faktual dan akurat mengenai faktafakta dan hubungan antara teori dengan fenomena yang diteliti. Data disajikan dengan prosentase dan dianalisis dengan analisis deskriptif, berpedoman pada butirbutir pertanyaan dalam kuesioner. Penelitian ini menggambarkan seberapa besar peran BKK di SMKN 2 Klaten dalam membantu menyalurkan siswanya ke dunia industri, yaitu siswa kelas XII DPIB SMK Negeri 2 Klaten dan hambatan-hambatan yang dialami oleh BKK serta upaya untuk mengatasinya.

Penelitian ini dilaksanakan di SMKN 2 Klaten, yang beralamatkan di Senden, Ngawen, Klaten, Jawa Tengah. Penelitian meliputi tahap persiapan, pelaksanaan, dan pelaporan dimulai pada bulan Juni sampai dengan Juli 2020.

Subjek penelitian didasarkan pada pertimbangan bahwa subjek tersebut dapat 
Peran Bursa Kerja Khusus ... (Fany/ hal. 175-189)

memberikan informasi yang relevan dan selengkap-lengkapnya dengan tujuan penelitian. Adapun pihak-pihak yang dijadikan sebagai subjek dalam penelitian ini adalah pihak-pihak yang dipandang dapat memberikan informasi yang selengkaplengkapnya tentang peran BKK dalam mengembangkan kesiapan kerja siswa kompetensi keahlian DPIB di SMKN 2 Klaten.

Pemilihan subjek penelitian ini menggunakan teknik purposive sampling, yaitu subjek penelitian yang dipilih berdasarkan kriteria dan pertimbangan bahwa subjek tersebut berkaitan langsung dengan peran BKK dalam mempersiapkan dan mengembangkan kesiapan kerja siswa kompetensi keahlian DPIB, sehingga diharapkan dapat memberikan informasi selengkap-lengkapnya. Subjek penelitian untuk mengumpulkan data dengan kuesioner adalah siswa kelas XII kompetensi keahlian DPIB tahun ajaran 2019/2020 sejumlah 65 siswa. Metode untuk menentukan jumlah sampel dari jumlah populasi responden adalah menggunakan nomogram Harry King.

\section{HASIL DAN PEMBAHASAN}

Penelitian ini dilakukan di SMKN 2 Klaten yang beralamat di jalan Senden, Ngawen, Klaten, Jawa Tengah. SMKN 2 Klaten dirintis pendiriannya pada tanggal 1 Agustus 1961. Berdasarkan SK Penegerian dan Direktorat Pendidikan Teknik No. 54/Dirpt/B.2/65, SMK N 2 Klaten resmi dikukuhkan pada tanggal 1 Januari 1965. SMKN 2 Klaten mempunyai 8 Program Keahlian, yaitu: 1) Teknik Fabrikasi Logam dan Manufaktur, 2) Teknik dan Manajemen Perawatan Otomotif, 3) Teknik Pengecoran Logam, 4) Teknik Tenaga Listrik, 5) Teknik
Elektronika Daya dan Komunikasi, 6) Sistem Informatika, Jaringan dan Aplikasi, 7) Konstruksi Gedung, Sanitasi dan Perawatan, 8) Desain Pemodelan dan Informasi Bangunan.

SMK N 2 Klaten sebagai lembaga pendidikan menengah kejuruan berusaha mencetak lulusan yang terampil untuk generasi bangsa. Setiap siswa dibekali dengan pengetahuan dan keterampilan sesuai dengan yang dibutuhkan oleh Dunia Usaha/Dunia Industri (DU/DI) seiring dengan perkembangan zaman. BKK

SMK N 2 Klaten secara garis besar mempunyai beberapa program, yaitu pengumpulan data siswa, pembekalan siswa yang akan memasuki dunia kerja, tes rekrutmen dari industri, pengiriman tenaga kerja ke industri, serta membina kerja sama dengan pihak pencari kerja untuk mengetahui kebutuhan kompetensi yang dibutuhkan untuk bekerja pada zaman sekarang. Sehingga BKK SMK N 2 Klaten bekerja sama dengan Dinas Tenaga Kerja dan Transmigrasi (Disnakertrans) kabupaten Klaten dan beberapa DU/DI untuk membantu persiapan dan penyaluran lulusan masuk dunia kerja.

Data hasil penelitian ini menyajikan hasil tentang pengumpulan data dari kuesioner tertutup yang berupa skor ideal, skor riil dan persentase pencapaian. Serta hasil wawancara dan berkas-berkas dokumentasi pada lampiran sebagai pendukungnya. Hasil penelitian ini bertujuan untuk mengetahui peran BKK SMKN 2 Klaten dalam menyalurkan siswa kompetensi keahlian Desain Pemodelan dan Informasi Bangunan ke dunia industri dan untuk mengetahui hambatan-hambatan yang dialami oleh BKK dalam melaksanakan program kegiatannya. Data hasil penelitian secara lengkap dapat dilihat sebagai berikut: 
a. Data Peran Bursa Kerja Khusus (BKK)

1) Pemberian layanan informasi ketenagakerjaan untuk siswa

Gambaran peran BKK dalam indikator layanan informasi ketenagakerjaan sebesar $85 \%$ masuk dalam kategori tinggi. Hasil tersebut diperoleh dari rata-rata 10 pernyataan yang ada dalam indikator tersebut, yaitu:

a) BKK mendata siswa sebagai pencari kerja.

b) Melakukan pendaftaran lowongan kerja untuk siswa.

c) Memberikan informasi mengenai lowongan pekerjaan melalui papan pengumuman.

d) Menghimbau siswa untuk mencari lowongan pekerjaan melalui BKK.

e) Memberikan informasi persyaratan pekerjaan kepada siswa.

f) Memberikan informasi mengenai jumlah kebutuhan tenaga kerja kepada siswa.

g) Memberikan informasi mengenai lingkungan pekerjaan kpada siswa.

h) Memberikan informasi mengenai pengupahan kerja kepada siswa.

i) Memberikan informasi mengenai rekrutmen tenaga kerja kepada siswa.

j) Menginformasikan adanya pameran bursa kerja (job fair) kepada siswa.

2) Penyelenggaraan bimbingan karir dan penyuluhan kerja kepada siswa

Gambaran peran BKK dalam indikator penyelenggaraan bimbingan karir dan penyuluhan kerja sebesar $83 \%$ masuk dalam kategori tinggi. Hasil tersebut diperoleh dari rata-rata 2 pernyataan yang ada dalam indikator tersebut, yaitu:

a) BKK mengadakan bimbingan karir untuk siswa. b) Mengadakan penyuluhn kerja kepada siswa.

3) Penyelenggaraan kegiatan rekrutmen, seleksi dan penyaluran tenaga kerja.

Gambaran peran BKK dalam indikator penyelenggaraan kegiatan rekrutmen, seleksi dan penyaluran tenaga kerja sebesar $85 \%$ masuk dalam kategori tinggi. Hasil tersebut diperoleh dari ratarata 4 pernyataan yang ada dalam indikator tersebut, yaitu:

a) BKK mengadakan rekrutmen tenaga kerja kepada siswa.

b) Melakukan seleksi tenaga kerja untuk siswa dengan beberapa tes.

c) Menawarkan kesempatan kerja kepada siswa saat ada lowongan pekerjaan yang didapat BKK.

d) Menawarkan kesempatan kerja sesuai dengan minat siswa.

4) Pelaksanaan sistem penelusuran lulusan

Gambaran peran BKK dalam indikator penelusuran lulusan sebesar $82 \%$ masuk dalam kategori tinggi. Hasil tersebut diperoleh dari rata-rata 3 pernyataan yang ada dalam indikator tersebut, yaitu:

a) BKK memberikan informasi mengenai pengisian formulir penelusuran lulusan.

b) Membagikan formulir penelusuran lulusan kepada siswa.

c) Memberikan informasi mengenai pembentukan ikatan alumni.

b. Data Kesiapan Siswa Mendapatkan Pekerjaan

Data ini diperoleh dengan membagikan kuesioner kepada 65 siswa kelas XII SMKN 2 Klaten kompetensi 
Peran Bursa Kerja Khusus ... (Fany/ hal. 175-189)

keahlian DPIB tahun ajaran 2019/2020. Kesiapan siswa untuk mendapatkan pekerjaan menjadi indikator acuan untuk melihat peran BKK dalam membantu penyaluran siswa DPIB SMKN 2 Klaten ke dunia industri. Hasil penelitian yang diperoleh mengenai gambaran kesiapan siswa untuk mendapatkan pekerjaan adalah sebagai berikut:

1) Siswa mempunyai pertimbangan dalam mencari pekerjaan

Gambaran kesiapan siswa untuk mendapatkan pekerjaan dalam indikator siswa mempunyai pertimbangan dalam mencari pekerjaan sebesar $76 \%$ masuk dalam kategori cukup. Hasil tersebut diperoleh dari rata-rata 4 pernyataan yang ada dalam indikator tersebut, yaitu:

a) Siswa terbantu dalam mencari pekerjaan dengan adanya informasi yang diberikan oleh BKK.

b) Siswa memilih pekerjaan dengan cara mencari informasi melalui BKK.

c) Siswa konsultasi dengan BKK dalam mencari pekerjaan.

d) Siswa sengan mencari pekerjaan jika BKK mengadakan job fair.

2) Siswa menguasai pengetahuan dalam bidang keahlian

Gambaran kesiapan siswa untuk mendapatkan pekerjaan dalam indikator siswa menguasai pengetahuan dalam bidang keahlian sebesar $78 \%$ masuk dalam kategori cukup. Hasil tersebut diperoleh dari rata-rata pernyataan yang ada dalam indikator tersebut, yaitu:

a) Siswa dapat menentukan pekerjaan sesuai dengan kemampuan. Bakat dan minatnya melalui bimbingan karir dari BKK. b) Siswa yakin dengan kemampuan yang dimilikinya bisa segera memperoleh pekerjaan.

c) Siswa memiliki keterampilan sesuai dengan bidang keahlian yang diminatinya.

d) Siswa mempunyai gambaran tentang bekerja mealui penyuluhan kerja dari BKK.

3) Kesiapan mental siswa

Gambaran kesiapan siswa untuk mendapatkan pekerjaan dalam indikator kesiapan mental siswa sebesar 78\% masuk dalam kategori cukup. Hasil tersebut diperoleh dari rata-rata 2 pernyataan yang ada dalam indikator tersebut,yaitu:

a) Siswa mengetahui syarat untuk mengikuti rekrutmen tenaga kerja yang diinfokan BKK.

b) Siswa mengisi data formulir penelusuran lulusan agar memudahkan BKK dalam menelusuri lulusan.

c. Hambatan BKK dalam Mengembangkan Kesiapan Siswa Mendapatkan Pekerjaan

Dalam pelaksanaan kegiatannya mempersiapkan siswa untuk mendapatkan pekerjaan, BKK tidak banyak mengalami kesulitan. Kondisi tersebut didukung dengan fasilitas yang cukup lengkap dari pihak sekolah. Hal lain adalah mekanisme kerja dari semua anggota BKK sudah berjalan dengan baik, sesuai tugasnya masing-masing sesuai bidangnya. Uraian tersebut sesuai dengan pernyataan Bapak Fajar selaku ketua BKK:

"Sejauh ini BKK SMK N 2 Klaten menjalankan kegiatannya dengan cukup baik. Hal tersebut didukung oleh fasilitas 
Peran Bursa Kerja Khusus ... (Fany/ hal. 175-189)

yang cukup lengkap dari sekolah, misalnya perlengkapan kantor BKK dan ruang serbaguna SMK N 2 Klaten sebagai tempat pembekalan dan tes rekrutmen. Serta semua pengurus BKK yang sudah menjalankan tugasnya dengan baik, seperti bidang hubungan indsutri yang mengadakan komunikasi dengan perusahaan-perusahaan untuk mencari informasi lowongn pekerjaan."

Dilihat dari kegiatan BKK sejauh ini, hanya perlu dioptimalkan lagi peran dari setiap anggota BKK untuk membantu menyiapkan/menyalurkan siswa/lulusan SMK N 2 Klaten ke dunia industri.

Meskipun peran BKK dalam menyalurkan lulusan ke dunia industri sudah baik, pada tahun ini 2020 akibat pandemi virus Covid-19, BKK juga mengalami kendala. Kendala tersebut adalah berkurangnya kerja sama dengan beberapa perusahaan. Secara tidak langsung hal tersebut menyebabkan BKK kekurangan/kesulitan dalam mencari informasi lowongan pekerjaan dari perusahaan.

\section{B. PEMB AHASAN}

\section{Peran Bursa Ke rja Khusus (BKK)}

Bagi para lulusan terdapat beberapa problem dan perlunya bimbingan karir pekerjaan, dibedakan dari kurun waktu, yaitu sebelum dan sesudah bekerja. Gambaran peran BKK SMKN 2 Klaten dapat dilihat pada tabel berikut:

Tabel 1. Presentase Peran BKK Secara Keseluruhan

\begin{tabular}{llll}
\hline No & Indikator & $\%$ & Kategori \\
\hline 1 & $\begin{array}{l}\text { Pemberian Layanan } \\
\text { Informasi ketenaga } \\
\text { kerjaan }\end{array}$ & $85 \%$ & Tinggi
\end{tabular}

\begin{tabular}{llll}
\hline No & Indikator & $\%$ & Kategori \\
\hline 2 & $\begin{array}{l}\text { Penyelenggaraan } \\
\text { bimbingan karir dan } \\
\text { penyuluhan kerja kepada } \\
\text { siswa }\end{array}$ & $83 \%$ & Tinggi \\
3 & $\begin{array}{l}\text { Penyelenggaraan } \\
\text { bimbingan karir dan } \\
\text { penyuluhan kerja kepada } \\
\text { siswa }\end{array}$ & $85 \%$ & Tinggi \\
& $\begin{array}{l}\text { Pelaksanaan sistem } \\
\text { penelusuran lulusan }\end{array}$ & $82 \%$ & Tinggi \\
\hline & Rata-rata & $84 \%$ & Tinggi \\
\hline
\end{tabular}

Berdasarkan Tabel 1 dapat dilihat bahwa presentase peran BKK dalam indikator pemberian layanan informasi ketenagakerjaan untuk siswa sebesar $85 \%$. Presentase dalam indikator penyelenggaraan bimbingan karir dan penyuluhan kerja kepada siswa sebesar $83 \%$. Presentase pada indikator penyelenggaraan kegiatan rekrutmen dan seleksi dan penyaluran untuk siswa sebesar $85 \%$. Presentase pada indikator pelaksanaan system penelusuran lulusan sebesar $82 \%$.

Secara keseluruhan presentase peran BKK SMKN 2 Klaten sebesar 84\% yang masuk dalam kategori tinggi. Hal ini menunjukkan bahwa peran BKK SMKN 2 Klaten dapat dikatakan tinggi dalam membantu menyalurkan lulusan DPIB ke dunia industri.

Peran Bursa Kerja Khusus (BKK) SMK N 2 Klaten dalam membantu menyalurkan siswa/lulusan DPIB ke dunia industri meliputi:

a. Memberikan layanan informasi kerja untuk siswa

Proses awal yang dilakukan BKK dalam membantu menyalurkan siswa/lulusan ke dunia industri, yaitu dengan melakukan pendataan kepada siswa yang berencana atau berminat bekerja setelah lulus, selanjutnya 
Peran Bursa Kerja Khusus ... (Fany/ hal. 175-189)

didata sebagai pencari kerja. Menurut

Sukardi dan Sumiati (2002: 112) mengemukakan bahwa: "Pada dasarnya informasi pekerjaan atau karir terdiri dari fakta-fakta mengenai pekerjaan, jabatan atau karir dan bertujuan untuk membantu individu memperoleh pandangan, pengertian dan pemahaman tentang dunia kerja dan aspekaspek dunia kerja". Cara yang digunakan adalah dengan membagikan blangko rencana siswa setelah lulus yang berisi beberapa pilihan, yaitu pilihan melanjutkan studi, bekerja dan berwiarausaha. BKK mendata siswa yang memilih bekerja dan selanjutnya didata sebagai pencari kerja.

BKK juga mencari atau mendata lowongan pekerjaan untuk siswa dengan cara mencari informasi lowongan pekerjaan atau ketika mendapat informasi lowongan pekerjaan dari perusahaan yang bekerja sama dengan BKK yang menghubungi BKK, baik dating secaralangsung atau melalui surat dan telepon.

Hasil wawancara dengan Bapak Fajar selaku ketua BKK didapatkan bahwa, BKK memberikan layanan informasi ketenagakerjaan kepada siswa, yaitu berupa lowongan pekerjaan, persyaratan kerja, rekrutmen tenaga kerja dan jumlah kebutuhan tenaga kerja. Informasi tersebut disampaikan dengan berbagai cara, yaitu menenpelkan surat informasi di papan pengumuman, mengirim pesan melalui media facebook dengan aplikasi whatssapp ke grup kelas melalui koordinator BKK di setiap jurusan, lowongan sesuai dengan bidang keahlian.

BKK juga memberi layanan secara langsung bagi siswa yang berkunjung ke ruang BKK untuk mencari informasi ketenagakerjaan.

Hasil penelitian ini menunjukkan bahwa program kerja BKK dalam memberikan layanan informasi ketenagakerjaan sudah tinggi.

Hal tersebut dibuktikan dengan kuesioner yang dibagikan kepada siswa menunjukkan presentase sebesar 85\% dan diperkuat dengan keterangan hasil wawancara kepada Bapak Fajar sebagai ketua BKK SMK N 2 Klaten.

b. Menyelenggarakan bimbingan dan penyuluhan kerja

BKK melakukan pembinaan dan pembekalan kerja untuk siswa berupa bimbingan karir dan penyuluhan kerja. Bimbingan yang diberikan bisa secara personal maupun umum seacara bersamaan.

Bimbingan karir adalah pengarahan dari BKK kepada siswa untuk persiapan karirnya. Siswa diarahkan untuk berkarir sesuai dengan bidang keahliannya maupun sesuai minatnya. Selain bimbingan karir, BKK juga mmengadakan penyuluhan kerja untuk siswa guna menyampaikan informasi terkait dunia kerja.

Penyuluhan kerja yang berisi materi bimbingan karir dan pengenalan dunia kerja diharapkan dapat menjadi bekal untuk siswa agar siap terjun memasuki dunia kerja setelah lulus dari pendidikan SMK.

Hasil penelitian ini menunjukkan bahwa kegiatan BKK dalam menyelenggarakan bimbingan kair dan penyuluhan kerja kepada siswa sudah tinggi. Hal tersebut dibuktikan dengan kuesioner yang dibagikan kepada siswa menunjukkan presentase sebesar $83 \%$ dan diperkuat dengan 
keterangan hasil wawancara kepada Bapak Fajar sebagai ketua BKK SMK N 2 Klaten.

c. Menyelenggarakan rekrutmen, seleksi dan penyaluran tenaga kerja

Pelaksanaan kegiatan rekrutmen dilakukan ketika ada perusahaan yang menghubungi BKK dan membutuhkan tenaga kerja. Perusahaan meminta bantuan BKK untuk melakukan rekrutmen kepada siswa/lulusan guna mengisi lowongan kerja yang tersedia di perusahaan. BKK melakukan rekrutmen dengan cara menyampaikan informasi lowongan kerja kepada siswa yang berminat dan sesuai kompetensi keahlian yang dibutuhkan. Setelah melakukan penawaran kerja, BKK mendata siswa yang bersedia mengisi/mendaftar lowongan kerja tersebut. Tahap selanjutnya adalah seleksi tenaga kerja. Seleksi tenaga kerja bisa dilakukan di sekolah atau di perusahaan sesuai permintaan dari perusahaan. Penyaluran tenaga kerja dilakukan apabila selesksi telah dilaksanakan dan mendapatkan siswa/lulusan yang memenuhi kriteria sesuai persyaratan yang dibutuhkan. Penyaluran siswa/lulusan berakhir setelah diterimanya lulusan sebagai tenaga kerja di perusahaan, dengan adanya konfirmasi dari salah satu pihak yaitu siswa/lulusan atau perusahaan melalui surat atau media elektronik (email/telepon).

Hasil penelitian ini menunjukkan bahwa kegiatan BKK dalam menyelenggarakan rekrutmen, seleksi dan penyaluran tenaga kerja sudah tinggi. Hal tersebut dibuktikan dengan kuesioner yang dibagikan kepada siswa menunjukkan presentase sebesar 83\% dan diperkuat dengan keterangan hasil wawancara kepada Bapak Fajar sebagai ketua BKK SMK N 2 Klaten.

d. Melaksanakan penelusuran lulusan Penelusuran lulusan termasuk dalam kegiatan rutin tahunan BKK yang dilakukan setiap tahun sekali yaitu setiap akhir/selesai satu tahun ajaran. Penelusuran lulusan dilakukan BKK dengan cara membagikan formulir penelusuran lulusan dengan google form melalui whatssapp, kepada siswa yang baru saja lulus/menyelesaikan studinya. BKK melakukan penelusuran guna mengetahui keberadaan dan kondisi lulusan setelah lulus, yaitu melanjutkan studi, bekerja atau berwirausaha serta untuk mencari informasi tambahan mengenai lowongan pekerjaan.

Hasil penelitian ini menunjukkan bahwa kegiatan BKK dalam menyelenggarakan rekrutmen, seleksi dan penyaluran tenaga kerja sudah tinggi. Hal tersebut dibuktikan dengan kuesioner yang dibagikan kepada siswa menunjukkan presentase sebesar $82 \%$ dan diperkuat dengan keterangan hasil wawancara kepada Bapak Fajar sebagai ketua BKK SMK N 2 Klaten.

\section{Kesiapan Siswa Mendapatkan Pekerjaan}

Berdasarkan Tabel 2 presentase kesiapan siswa untuk mendapatkan pekerjaan sebesar 77\%. Presentase pada indikator siswa mempunyai pertimbangan dalam mencari pekerjaan sebesar $76 \%$. Presentase pada indikator siswa menguasai pengetahuan dalam bidang keahlian sebesar 78\%. Presentase kesiapan mental siswa sebesar $78 \%$. Gambaran kesiapan siswa 
Peran Bursa Kerja Khusus ... (Fany/ hal. 175-189)

untuk mendapatkan pekerjaan dapat dilihat pada tabel berikut:

Tabel2. Kesiapan Sis wa untuk Mendapatkan Pekerjaan

\begin{tabular}{clcc}
\hline No & \multicolumn{1}{c}{ Indikator } & $\%$ & Kategori \\
\hline 1 & $\begin{array}{l}\text { Siswa mempunyai } \\
\text { pertimbangan dalam } \\
\text { mencari pekerjaan } \\
\text { Siswa menguasai } \\
2\end{array}$ & $\begin{array}{l}\text { pengetahuan dalam } \\
\text { bidang keahlian } \\
\text { Kesiapan mental } \\
\text { siswa }\end{array}$ & Cukup \\
\multicolumn{1}{c}{ Rata-rata } & Cukup \\
\hline T7\% & Cukup \\
\hline
\end{tabular}

Secara keseluruhan presentase kesiapan siswa untuk mendapatkan pekerjaan sebesar 77\% masuk dalam kategori cukup. Hal ini menunjukan bahwa siswa kelas XII DPIB SMKN 2 Klaten sudah cukup siap untuk mendapat pekerjaan dan memasuki dunia pekerjaan.

Penjelasan mengenai kesiapan siswa untuk mendapatkan pekerjaan dengan adanya peran dari BKK dalam mempersiapkan siswa dalam memasuki dunia kerja sebagai berikut:

a. Mempunyai pertimbangan dalam memilih pekerjaan

Indikator pertama yaitu siswa mempunyai pertimbangan dalam memilih pekerjaan. Indikator tersebut dijabarkan melalui 4 pernyataan yaitu, siswa terbantu dalam mencari pekerjaan dengan adanya informasi yang diberikan oleh BKK dengan presentase $79 \%$. Siswa memilih pekerjaan dengan cara mencari informasi melalui BKK dengan presentase $74 \%$. Siswa konsultasi dengan BKK dalam mencari pekerjaan dengan presentase $75 \%$. Siswa senang mencari pekerjaan jika BKK mengadakan job fair dengan presentase $77 \%$. Dari keempat pernyataan tersebut yang termasuk dalam indikator siswa mempunyai pertimbangan dalam memilih pekerjaan diperoleh rata-rata presentase sebesar $76 \%$, masuk dalam kategori cukup. Nilai tersebut ditunjukkan oleh siswa yang menyatakan bahwa siswa sudah cukup mempunyai pertimbangan dalam memilih pekerjaan yang sesuai dengan kompetensi keahliannya. Hal ini menunjukkan bahwa peran BKK dengan berbagai program yaitu, memberikan informasi ketenagakerjaan dan bimbingan karir serta penyuluhan kerja cukup baik dalam memperisapkan siswa untuk memasuki dunia kerja.

b. Mengetahui pekerjaan yang sesuai dengan kompetensi

Indikator selanjutnya adalah siswa mengetahui pekerjaan yang sesuai dengan kompetensi. Indikator tersebut dijabarkan melalui 4 pernyataan, yaitu siswa dapat menentukan pekerjaan sesuai dengan kemampuan, bakat dan minat melalui bimbingan karir dari BKK dengan presentase sebesar $80 \%$. Setelah mendapat bantuan dari BKK siswa yakin dengan kompetensi yang dimiliki, siswa dapat segera memperoleh pekerjaan dengan presentase sebesar $79 \%$. Siswa memili keterampilan sesuai dengan bidang keahlian yang diminati dengan presentase sebesar $82 \%$. Siswa mempunyai gambaran tentang bekerja melalui penyuluhan kerja dari BKK dengan presentase sebsar $72 \%$. Dari keempat pernyataan tersebut yang termasuk dalam indicator siswa mengetahui pekerjaan yang sesuai 
dengan kompetensi diperoleh rata-rata presentase sebesar 78\% masuk dalam kategori cukup. Nilai tersebut ditunjukkan oleh siswa yang menyatakan bahwa siswa sudah cukup mengetahui pekerjaan yang sesuai dengan kompetensi keahlian mereka. Artinya secara rata-rata siswa/lulusan sudah cukup mengetahui pekerjaan apa yang sesuai dengan kompetensi keahlian yang mereka miliki. Kondisi ini menunjukkan bahwa bimbingan karir dan penyuluhan kerja yang diberikan oleh BKK kepada siswa sudah cukup membantu siswa mengetahui bidang pekerjaan yang sesuai dengan kompetensi keahlia siswa. Untuk meningkatkan peran tersebut diharapkan siswa lebih aktif dan memahami bimbingan karir dan penyuluhan kerja yang diberikan oleh BKK.

c. Kesiapan mental

Indikator terakhir adalah kesiapan mental siswa. Dalam penelitian ini indikator kesiapan mental siswa dijabarkan melalui 2 pernytaan yang terdapat di dalamnya yaitu, siswa mengetahu syarat untuk mengikuti rekrutmen tenaga kerja yang diinfokan BKK dengan presentase $75 \%$. Siswa mengisi data formulir penelusuran lulusan agar memudahkan BKK dalam menelusuri lulusan dengan presentase $82 \%$. Dari 2 pernyataan tersebut diperoleh rata-rata presentase sebesar $78 \%$ masuk dalam kategori cukup. Nilai tersebut ditunjukkan oleh siswa yang menyatakan bahwa mereka sudah cukup mengetahui dan memahami proses mengikuti rekrutmen dan seleksi tenaga kerja. Artinya secara rata-rata siswa kelas
XII DPIB SMK N 2 Klaten sudah cukup mengetahui dan memahami proses mengikuti rekrutmen dan seleksi tenaga kerja.

Kondisi ini menunjukkan bahwa kegiatan bimbingan karir dan penyuluhan kerja serta informasi tentang rekrutmen dan seleksi tenaga kerja dapat dimengerti oleh siswa guna mempersiapkan mentalnya untuk memasuki dunia kerja. Proses untuk memasuki dunia kerja adalah siswa mengikuti rekrutmen dan seleksi yang diadakan oleh perusahaan melalui kerjasama dengan BKK. Proses rekrutmen dan seleksi bisa dilakukan di perusahaan atau di sekolah sesuai dengan permintaan perusahaan. Kegiatan yang dilakukan oleh BKK diharapkan dapat berjalan terus guna membantu siswa mempersiapkan diri memasuki dunia kerja dan diharapkan siswa dapat mengikuti dan memanfaatkan kegiatan tersebut secara optimal.

\section{Hambatan BKK dalam Mengembangkan Kesiapan Siswa Mendapatkan Pekerjaan}

Dari uraian pembahasan di atas, peran BKK SMKN 2 Klaten dalam membantu menyalurkan lulusan ke dunia kerja sudah cukup tinggi. Kondisi tersebut didukung dengan beberapa hal berikut ini:

a. Fasilitas

Fasilitas menjadi salah satu faktor penting yang menjadi pendukung BKK dalam menjalankan program kerjanya untuk membantu menyiapkan/ menyalurakan siswa/ lulusan ke dunia kerja. Beberapa fasilitas yang ada yaitu: 
Peran Bursa Kerja Khusus ... (Fany/ hal. 175-189)

1) Ruang BKK yang sudah tersedia dan layak untuk operasional BKK. 2) Gedung serba guna SMK N 2 Klaten, yang bisa digunakan BKK untuk mengadakan bimbingan karir dan penyuluhan kerja untuk siswa. 3) Perlengkapan yang cukup di ruang BKK, yaitu meja, kursi, komputer, printer, wifi yang semuanya dalam keadaan baik. Beberapa hal tersebut mendukung BKK untuk beroperasi secara optimal.

b. Kepengurusan

Dalam menjalankan kegiatannya, semua anggota BKK sudah berperan aktif dan baik sesuai fungsi dan tugas masingmasing. Ketua BKK, Bapak Fajar melakukan koordinasi dengan baik dengan semua anggota pengurus BKK. Koordinator bidang hubungan industri, Bapak Purwoko berperan aktif dalam mencari informasi lowongan pekerjaan dengan komunikasi kepada perusahaan. Setelah didapatkan informasi lowongan pekerjaan dari perusahaan, lowongan tersebut diteruskan kepada siswa/lulusan pencari kerja. Kemudian BKK mengadakan rekrutmen, seleksi dan penyaluran tenaga kerja ke perusahaan.

Meskipun peran BKK dalam menyalurkan lulusan ke dunia industri sudah baik, pada tahun ini 2020 akibat pandemi virus Covid-19, BKK juga mengalami kendala. Kendala tersebut adalah berkurangnya kerja sama dengan beberapa perusahaan. Secara tidak langsung hal tersebut menyebabkan BKK kekurangan/kesulitan dalam mencari informasi lowongan pekerjaan dari perusahaan.

\section{SIMPULAN}

Berdasarkan hasil penelitian dan pembahasan yang telah dipaparkan pada bab sebelumnya, maka kesimpulan dalam penelitian ini adalah sebagai berikut:

Peran Bursa Kerja Khusus (BKK) SMKN 2 Klaten secara keseluruhan sangat berperan dalam membantu penyaluran kerja siswa kompetensi keahlian Desain Pemodelan dan Informasi Bangunan (DPIB) dengan presentase mencapai $84 \%$. BKK menjalankan perannya dengan berbagai kegiatan yang telah dilakukan yaitu, sebagai pemberi pelayanan informasi ketenagakerjaan untuk siswa, mengadakan bimbingan karir dan pembekalan kerja untuk siswa, menjalin kerja sama dengan perusahaan, melakukan kegiatan rekrutmen dan penyaluran tenaga kerja, serta melakukan penelusuran lulusan.

Kesiapan siswa untuk mendapatkan pekerjaan secara keseluruhan sudah cukup dengan presentase $77 \%$. Kesiapan siswa untuk mendapatkan pekerjaan tersebut didapatkan melalui beberapa indikator yaitu siswa mempunyai pertimbangan dalam memilih pekerjaan, siswa mengetahui pekerjaan yang sesuai dengan kompetensinya dan kesiapan mental siswa yang sudah cukup siap untuk memasuki dunia kerja.

Secara umum tidak ditemukan hambatan khusus di BKK SMKN 2 Klaten dalam menyalurkan siswa ke dunia kerja. Fasilitas BKK lengkap dan dengan kondisi yang baik, diantaranya yaitu ruang BKK, gedung serbaguna SMKN 2 Klaten dan perlengkapan kerja di ruang BKK. Kepengurusan sudah berperan aktif sesuai fungsi dan tugasnya masingmasing.Meskipun peran BKK dalam menyalurkan lulusan sudah cukup baik, namun pada tahun ini 2020 akibat pandemi Covid-19, BKK mengalami kendala yaitu berkurangnya kerjasama dengan beberapa perusahaan. Hal tersebut menyebabkan 
Peran Bursa Kerja Khusus ... (Fany/ hal. 175-189)

BKK kekurangan/kesulitan dalam mencari informasi lowongan pekerjaan. Upaya yang dilakukan BKK untuk mengatasi hambatan pemutusan hubungan kerjasama akibat pandemi Covid-19 dengan perusahaan adalah BKK melalui humas akan mencari dan melakukan pendekatan kepada perusahaan untuk menjalin kerjasama dalam hal penyaluran tenaga kerja.

\section{DAFTAR RUJUKAN}

Ardana, I. K. \& Mujiati, N. W. \& Utama, I.M. (2012). Manajemen Sumber Daya Manusia, Yogyakarta. Graha Ilmu.

Depnaker \& Transmigrasi RI, Dirjen Binapenta. (2001). Petunjuk Teknis Bursa Kerja Khusus. Jakarta: Depnarkertrans RI.

Hafsah M J (2005). Kemitraan usaha. Jakarta: Pustaka Sinar Harapan.

Hasibuan, M S P 2007, Manajemen Sumber Daya Manusia Perusahaan, Bandung, PT. Bumi Aksa.

Klaus S (2017). The Fourth Industrial Revolution. New York: Crown Bussines.

Mangkunegara, A.P. (2009). Manajemen Sumber Daya Manusia Perusahaan. Bandung: PT Remaja Rosdakarya.
Masdarini L. (2014). Usaha-usaha Penyaluran Lulusan Sekolah Menengah Kejuruan Melalui Optimalisasi Peran Bursa Kerja Khusus. Jurnal Pendidikan Teknologi dan Kejuruan. Universitas Pendidikan indonesia. (VII). Hlm 589-595.

Mulyaningtyas B R dan Hidayanto $\mathrm{Y}$ P (2006). Bimbingan dan Konseling untuk SMU Kelas XI. Jakarta: Erlangga.

Musnamar Thohari, 1992, Dasar-dasar Konseptual Bimbingan Konseling Islam, Yogyakarta : UII Press.

Peraturan Pemerintah Nomor 74 tahun 2008 Tentang Guru.

Sastrohardiwiryo B S, 2005. Manajemen Tenaga Kerja Indonesia:Pendekatan Administratif dan Operasional. Jakarta: Bumi Aksara.

Sugiyono. (2009). Metode Penelitian Kuantitatif, Kualitaatif, $\quad R \& D$. Bandung: Alfabeta.

Sukardi dan Sumiati. (2002). Pedoman Praktis Bimbingan Penyuluhan di Sekolah. Jakarta: PT. Rineka Cipta.

Usman, H. (2012). Kepemimpinan Pendidikan Kejuruan. Yogyakarta: UNY Press. 